ETGES, B. M. B. S., Pereira, B. B., Silveira, T. J. S. (2018) "A Lean approach to improve productivity in a coke oven refurbishment project: a case study" In: Proc. $26^{\text {th }}$ Annual Conference of the International. Group for Lean Construction (IGLC), González, V.A. (ed.), Chennai, India, pp. 1111-1121. DOI: doi.org/10.24928/2018/0254. Available at: www.iglc.net

\title{
A LEAN APPROACH TO IMPROVE PRODUCTIVITY IN A COKE OVEN REFURBISHMENT PROJECT: A CASE STUDY
}

\author{
Bernardo Martim Beck da Silva Etges ${ }^{1}$, Bruno Bronzatto Pereira², \\ Thiago José Salgado da Silveira ${ }^{3}$
}

\begin{abstract}
This paper presents a 3-phased Lean Construction Project (LCP) implemented in a specialized and integrated service company. The purpose of the LCP was to increase productivity and to re-structure Production Planning and Control routines. It was undertaken by a group of internal and external consultants for a period of four months of workshops and more four months of sustainability on-site. The construction project focused by the LCP was the refurbishment of a Coke Oven in a Brazilian Steel Mill.

The three workshops regarding the Lean Construction background were: (a) Analysing the construction activities and support process (Planning, Contract Management, Supply, Warehouse, Safety); (b) Redesigning Production Planning and Control tools, routines and responsibilities; and defining a new Work plan schedule regarding takt-time; and (c) a Productivity Workshop implemented through wastes identification, activities reorganization and work provision. For all these workshops, a work group was formed covering consultants, managers, engineers, team-leaders and front-line workers. Finally, the workshop results were assessed through comparison of the productivity indicators with the base-line defined in the Analysis Stage.

After the LCP, the project achieved its main objective with the walls assembly productivity improvement by $20 \%$. This result was reached with fewer people performing more efficiently (less time). Moreover, the operational efficiency improvement guaranteed a $46 \%$ increase in the gross margin of the contract.
\end{abstract}

\section{KEYWORDS}

Production Planning and Control, Productivity, Lean Construction

M.Sc. Eng, Project Manager, Steinbock Consulting, Etges Engenharia, Porto Alegre, Brazil;

bernardo.m.etges@gmail.com

Mechanical Eng., RIP-Kaefer, Indaiatuba, Brazil; bruno.bronzatto@kaefer.com

Lean Coordinator., RIP-Kaefer, Indaiatuba, Brazil; thiago.silveira@kaefer.com 


\section{INTRODUCTION}

At a time of great political and economic instability in Brazil, service and transformation industries, to ensure returns on their investments, more and more require their suppliers to be positioned competitively. Companies which provide construction, maintenance and mechanical assembly services, in order to guarantee revenue and a minimum profitability for the business without adversely affecting the product quality that is delivered to the customer, inevitably seek a trade-off that includes ways to cut costs.

More than ever, strategies to redesign the production chain, to analyse internal and operational processes, and to seek alternatives and opportunities to produce in an increasingly efficient way are objectives of organizations that seek to sustain themselves and grow in the market (Sage et al. 2012).In this background the current case study was developed in a company which provides repair, construction and industrial maintenance services, which in this article is called Company A, with market focused on the transformation industry (steel and petrochemicals). Since 2013, Company A has been investing in implementing tools and concepts towards a Lean culture in its projects and throughout the organization as its improvement approach

Given this macroeconomic and organizational context, this article presents a case study developed in one of Company A's projects. The construction contract, focus of this paper, concerns a Lean Construction Project (LCP) to increase productivity in a refurbishment of coke oven in a Brazilian Steel Mill. To do so, the paper was divided into a general objective and specific objectives:

The general objective of the study was to increase the operational efficiency of the coke oven refurbishment case study by increasing its productivity. To achieve the general objective, three specific objectives were proposed: (a) To catch the delay in the first phase (step 1) of the construction project; (b) To structure the contract planning process by drawing up long-and medium-term plans using the takt time; (c) To implement a system for managing the routines and production control considering takt time and the Last Planner methodology; (d) To balance and stabilize refractory assemblage by making use of improvement initiatives.

For reasons of contractual secrecy, the actual numbers of employees, costs and real profit margin will not be presented. All results will be presented in a percentage rate.

The paper presents the methodological stages of Lean implementation, the tools used, the results obtained and the transition to sustain the routines and the obtained results. Thus, the structure of this article is as follows: After this introduction, Chapter 2 describes Company A and the project. Chapter 3 sets out the theoretical basis for the project while Chapter 4 introduces the methodology and tools used. Chapter 5 presents the results and Chapter 6 draws some conclusions, and points out some limitations and suggestions for further study which are expressed as challenges to tackle sustainability. 


\section{PROJECT AND COMPANY A DESCRIPTION}

Company A was founded in 1986 and have been integrated with its current German parent company in December 2014, provides customizable integrated services for several industrial segments, including Refractory, Thermal Insulation, Anticorrosion Protection, Passive Protection, Access, Electromechanical, Construction, Facilities Services, Operation and Maintenance of Energy Assets, as well as Offshore services such as maintenance, interior outfitting, crane operation and cargo handling.

In a scenario of high operational complexity and technical requirements of low predictability, the Lean Initiative was proposed for optimizing resources in works for refurbishing a coke oven in an integrated steel mill in Brazil. The hot repair of a coke plant is a strategic project for steel mills. First of all, this is because provides the carbon component that steel is produced with, and because the coke oven is critical to the Mills energy balance. The scope of the contract foresees the hot repair of 253 combustion chambers of the steel plant. The contract was implemented over 6 phases, called "steps". The scope of the repair comprises, in a simplified form: (a) removing the metal structure, (b) demolishing existing walls to their floor, (c) evaluating the quality of the refractory floor, and (d) constructing new walls to the top, a stage that is called refractory assembly. The service is conducted under conditions of high temperature and the presence of harmful gases. Due to these critical conditions, the front-line workers act under a regime of relay labour shifts, which must meet Brazilian labour regulations. This relay, in its best hypothesis, occurs at a rate of 30 minutes on and 30 minutes off. Therefore, the present contract has always dimensioned and considered that at least double the number of workers are needed to staff this activity.

\section{BACKGROUND}

The approach proposed by Company A as the focus of its process improvement program is called the Lean Journey. Its methodological foundation stems from the fundamental concepts of Lean Production (Shingo, 1988, 1989), Womack and Jones (1990), Spear and Bowen (1999) and Liker (2004). Synchronizing the production activities, reducing stocks, reducing set-up cycle time and having quality assurance are addressed by Shingo (Shingo, 1988, 1989). Later, Womack and Jones (1990), Spear and Bowen (1999), Liker (2004) re-assessed Lean Production principles and prioritized the focus on value for customer, as well as improving the ideas of flow, quality and wastes reduction. Later, Company A, also incorporates concepts that are derived from Lean Production and contextualized within Construction. Since 1992, it has been called Lean Construction (Koskela, 1992).

From the joint analysis of this theoretical evolution, Company A based its Lean approach on 4 fundamental principles: (a) Flow; (b) Takt time (rhythm); (c) Pull; (d) zero failure. Thus, the principle of (a) flow relates the work crew dimensioning, connecting them in accordance with a logical sequence of activities. The activities are, then, classified in accordance its responsibilities and information's inputs and outputs. The principle of (b) takt defines that Takt time is the unit of time within which a product must be produced in order to match the rate at which that product is needed (Hopp and 
Bernardo Martim Beck Da Silva Etges, Bruno Bronzatto Pereira, Thiago José Salgado Da Silveira

Spearman, 2008). Takt time is seen as a target definition for work structuring to design the production system for continuous promptly to flow (Frandson et al., 2015; Frandson et al., 2013). In accordance with the takt, it is expected to define the size of the teams, resources and inputs (Frandson, et al. 2013).The principle of (c) Pull is a fundamental pillar of Lean Production (Shingo, 1998), in which stocks are eliminated and production is defined to serve the customer at the speed (takt) he wishes. And, finally the principle of (d) Zero Failure is established; which also refers to another pillar of Lean Production (Womack and Jones, 1990) which comes from the underlying principle of Total Quality Control, which seeks to standardize and stabilize processes. Among those four principles, the Last Planner System (Ballard, 2000) will be implemented for Planning Process and the concepts of wastes defined by Ohno (1988), will be considered in the Productivity Workshop.

\section{METHODOLOGY}

The project developed in company A, in partnership with a consulting firm, was a group of workshops which were held over a period of twelve weeks. These were divided between (a) Analysis, (b) Production Planning and (c) Productivity. After these four months, Company A kept the Lean Project running under internal management for more four months focused on keep the improvements on track. Figure 1 illustrate the LCP Work plan.

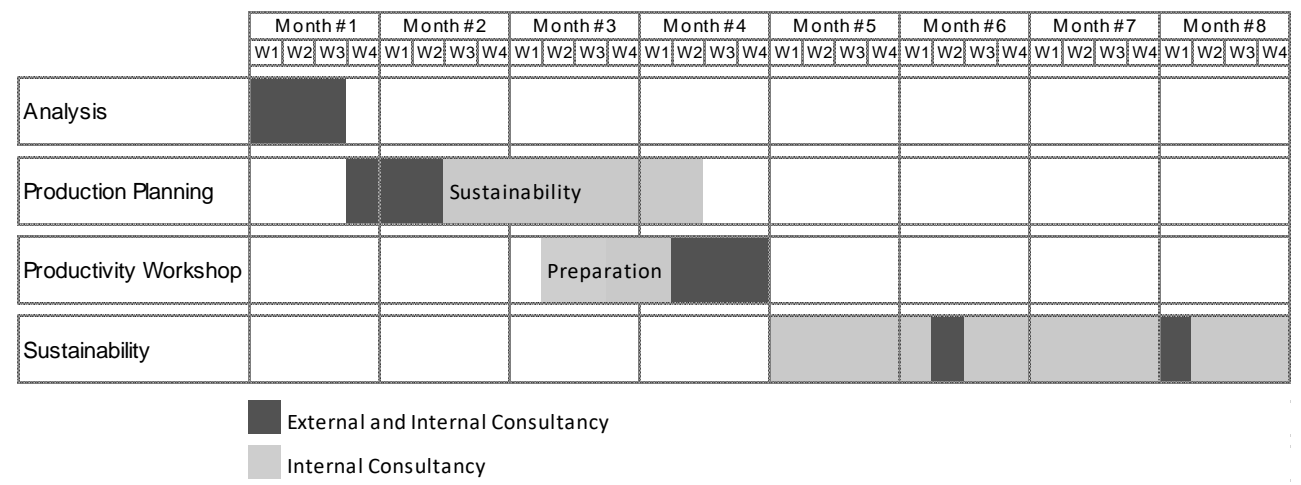

Figure 1: LCP Work plan

\section{ANALYSIS}

The start of any project is defined as being when project staff become familiar with the company's productive and support processes (planning, supplies, engineering, and so forth); get to know the project leadership team; and analyse the company's current performance. Thus, the first three weeks of work in the Construction Project, were defined as having this objective.

The Analysis of the project makes use of the following tools:

- Overall Process Analysis (OPA): a step in which the value chain is observed and the whole project team defines sources of problems, rework, or neglected step. 
- Gemba and waste analysis: the 7 losses defined by Ohno (1988) (Overproduction, Defects Products, Movement, Over processing, Inventory, Waiting and Motion) are used as references. In order to identify these wastes and their impacts, the following tools are used: (a) Waste Walk, which consists of observing and finding evidence of the aforementioned losses; (b) Multi Moment Analysis, a count of people who add value or for some of the types of the seven losses, an analysis of several consecutive intervals of time; (c) Chrono-analysis, which consists of an unbroken period of filming over a long period (minimum of 4 hours) to observe the level of value added in complete cycles of activities.

- Semi-structured interviews with leaders: conduce interviews with the team leaders and understand from their perspective the project, its problems and opportunities.

- Performance and financial indicators analysis: They support the zero line of the Lean project and support the understanding of how performance and how the project results are presented to the Company Board.

The complete analysis allowed the consultants to understand the project. The baseline was defined by the contract managers in the very beginning of the refurbishment mobilization considering planning, budget and profit margin. Since the beginning of the first refurbishment step (Step 1), Company A recognized problems that should be controlled for the success of the contract.

The closure of the analysis stage consists of presenting the material developed to the project Board of Directors define a Work plan Workshops and an action plan can be implemented rapidly and which may have a high impact also emerge. These include: controlling overtime, resizing of night-shift teams, reviewing required capacity for hoisting equipment and because of its managerial characteristics will not be detailed in this paper.

\section{PRODUCTION PLANNING}

Koskela (2000) discussed the importance of TFV (Transformation, Flow and Value) concepts in construction, in which he argues that the aspect of flow is often forgotten in traditional production management models. The author realizes that this aspect can also be applied to the flow of information, which directly affects the flow of resources and has a fundamental role in integrating lean into production management (Dave et al., 2010, Sacks et al., 2010).

With the objective of restoring the flow of information, to continue to take this information to the field crew, to control production and ensure the takt time (Company A Second Principle), the planning workshop was divided into three sub-stages: (a) Mapping of the planning process, defining the responsibility matrix and work schedule of the office team; (b) Review of the production strategy and takt needed of each step of the project; (c) implementing Last Planner for daily field management (at every shift) with the team involved on production. 
Bernardo Martim Beck Da Silva Etges, Bruno Bronzatto Pereira,

Thiago José Salgado Da Silveira

\section{Mapping of the Planning Process}

For this stage, a Workshop was designed with the planning team. It began with mapping the Planning process including all activities that were carried and those that had some standardization problems and activities that are not implemented in the routine of the sector.

Next, the responsibility matrix was dimensioned considering the activities that each member addresses. Thus, a working agenda for the team was defined, including decisionmaking meetings that should be taking in accordance with other members, like the monthly schedule, for example. For the activities which presented problems, corrective actions were defined and for those not implemented, tools and internal control standards were developed, as will be detailed in item 4.2.3 regarding to short-term planning and control. Figure 2a illustrates the Workshop of mapping the planning process.

\section{Production Strategy - takt time}

At the start of the project, the internal team defined a work plan and sized a standard team to carry out each modality considering the productivity defined in the budget (historic data from previous projects of coke oven refurbishment conducted by Company A). The results from the first step due to internal inefficiencies and difficulties of the client's own releases were of low productivity ( $7 \%$ over the budget). For the continuity of the project Company A defined the necessity of improving productivity and reduce costs.

A change to improve productivity necessarily undergoes review of the entire production process. Thus, in the Planning Workshop, the flow (sequence) of activity and takt time at which they are carried out was put under review in rounds of work with the Planning and Production teams (Mechanical and Civil team). Frandson et al. (2015) concludes that takt time deals with visual workplace to make clear to all (on and off site), who is doing the work, where, and in which pace in order to distribute control.

The methodology used sought in this Workshop to define the sequence of activities, their maximum duration in accordance with the target defined by the client and define the size of the front-line labours to reach the necessary takt time. The Production Strategy also sought to identify restrictions that could compromise the takt time (on materials, labour, equipment or the in the design). Figure $2 \mathrm{~b}$ illustrates the outcome of the study.

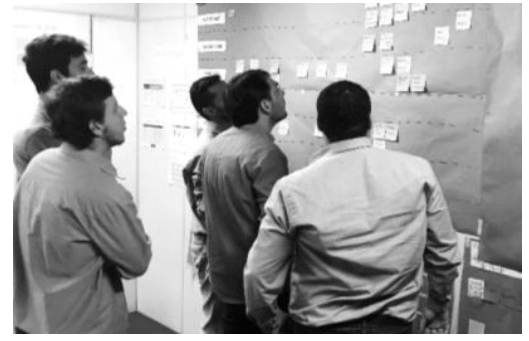

Figure 2a: Planning Workshop

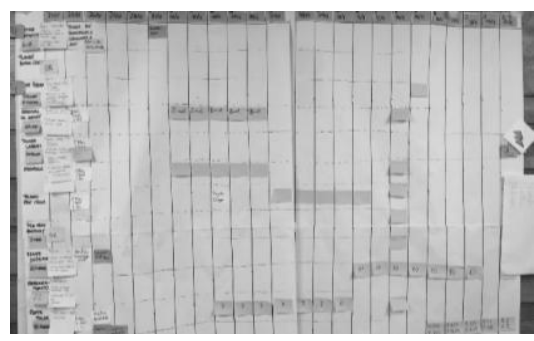

Figure 2b: Planning Step 2 


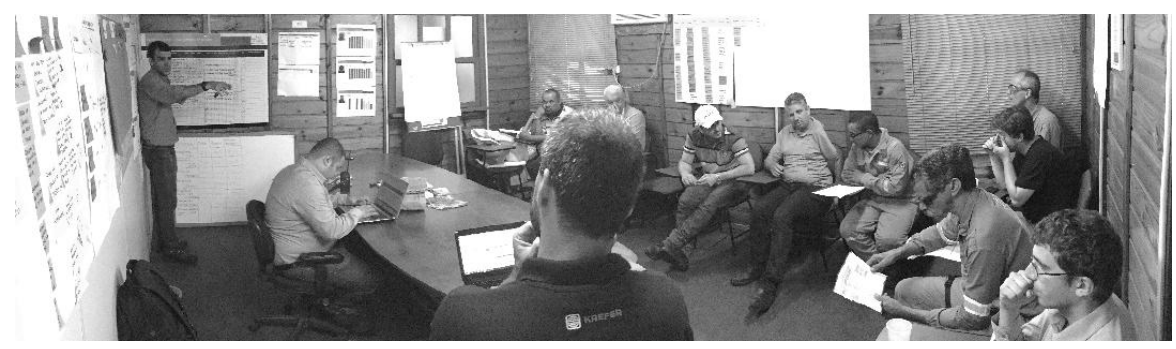

Figure 2c: Meetings to control targets when shifts change

\section{Production Management}

One of the main inefficiencies of planning was the delay to have the right information in the necessary time. The activities developed were monitored and deviations were controlled but these were done by greatly detaching of time from production. In order to contain this inefficiency and to help the work to maintain the pace set for reaching the deadline, a simple system was proposed based on the Last Planner System (Howell and Ballard, 2007). The goal was to define production activities, the person responsible and the deadline for completing each of this small amount of work. At the changeovers of shift (7:00 a.m. and 5:00 p.m.), a meeting was conducted by the planning team along with foremen and engineers, the quality and safety responsible. At this quick meeting, the conduct of each activity was reviewed, the cause of the deviations was controlled and the activities for the start of the next shift were reviewed. Figure $2 \mathrm{c}$ illustrates an example of the meetings for controlling production targets. Thus, successively, at each shift, the entire leadership team had full information about the progress of the activities its problems and the action plan needed to keep the takt.

\section{PRODUCTIVITY}

This chapter consists of the stage when the fundamental tools of Lean Production are most applied. The Productivity Workshop is divided into 7 standardized phases consisting of (a) Team training; (b) Initial survey of the data; (c) Analysis of the Current Process (Mapping the Value Stream); (d) Defining and Prioritizing Solutions; (e) Implementing Improvements; (f) Verifying Improvements; and (g) Standardizing the Process. All these phases are conducted with the coordination and operational team (managers and technicians) of the activity focused on and the change is implemented in a short period. In this case, the Workshop was made conducted in three weeks and the work changes were applied during the next constructions steps. The productivity improvement will be measured considering the rate of total front-line workers hours spend to assemble 1 ton of refractory brick-wall. This is described as man hour per ton (mh/ton)

Thus, we defined the work team for the Workshop, involving 2 managers and three bricklayers, a coordinator engineer, and a production and planning manager. They were trained on matters that address the concepts of rhythm, flow, pulled production and zero failure, and to identify and recognize the seven wastes in production. In parallel, the consultants collected current production data, such as the plan of attack, the number of people involved, the productivity achieved, and interruptions in the production process. 
Bernardo Martim Beck Da Silva Etges, Bruno Bronzatto Pereira, Thiago José Salgado Da Silveira

In the third step of the work, the following activities were mapped: the construction process; its support activities and conditions of supplies and providing the production fronts with materials, equipment and labour. Therefore, by using the methodology of OPA, that consist of a tool which was adapted from Value Stream Mapping (VSM) (Rother and Shook, 2000) for the Lean projects in Company A. What distinguishes OPA from the classic VSM is that, at this initial moment, the teams and productivity indexes for each step are not quantified. In the design and construction of OPA, the focus is to understand the sequence of activities and, from the outset, to prompt the project team to identify failures and wastes.

After the process has been mapped, the Workshop team engages on field-work in order to identify and quantify failures and wastes. The team is split up so as to cover some formats of analysis that include: Identifying the seven wastes; a spaghetti diagram; a multi-moment analysis for periods of at least one hour of observation. The consultants are responsible for recording the chrono-analysis so as, later, to quantify the wastes. Usually the simplest forms of analysis (identifying wastes and the spaghetti diagram) are intended for members with a lower level of formal education.

After making the observations in the Project Analysis step and the field observations, the wastes and the number of people involved in each step of the activity are quantified and the Operator Balance Chart (OBC) of the current state is defined. Subsequently, using the contractual deadlines, the period of net production is calculated, and consequently, what rate of production must be followed in order to reach the contractual milestones. Thus, at the end of the third stage of the Workshop, we have the map of the current state of the refractory assembly process, the OBC in this current state and the takt time needed to reach the delivery dates of the project.

Therefore, the fourth step of the workshop consists of defining an Action Plan to implement improvements in the productivity of the service front of the refractory assembly focused on achieve takt time. Thus, actions of change in the sizing of the teams, the attack plan, tools and devices used in running and systems that supply service fronts were implemented. Actions are prioritized after an analysis is made of the potential improvement $\mathrm{v}$ the financial effort made by the management and coordinators of the work. In the fifth step of the Workshop, these actions are implemented and monitored. The standardization of the Process, as the seventh step of the Predicted Workshop occurred at the end of the work, in which Company A started to incorporate the improvements achieved.

\section{RESULTS}

The results of the Lean Project implemented by Company A in partnership with the Consulting Company were achieved after the four stages outlined in chapter 4. Table 1 presents the main results obtained. From the analysis stage, the main results are the Project deep understanding. Quantifying inefficiencies showed that 59\% of activities do not add value in the refractory wall assembly, for example: (a) were identified the waste of $23 \%$ in the shift due the temperature during the wall assemblage (average of seven

minutes in each shift change of 30 minutes); (b) errors on bricks transportation and 
delivery to the oven assemblage caused a large amount of waiting time of labours inside the oven; (c) lack of proper transport devices made labours walk until seven times to transport bricks on hand. Another important indicator was identified verifying the planning routines that showed that only $27 \%$ of the standards set are really used for the Planning and Control, for example, long time to have field information (problems and daily production), week plans were done only by planning members; lack of feedbacks on planning review.

The Planning Workshop has the characteristic of being a structuring Workshop, as it encourages a reorganization of activities, tools and control standards, besides defining and implementing indicators and acting on the team's motivation. Throughout the project (about 6 months after the Workshop period), the team reached 93\% of the standards for Project Planning and Control (previously was 27\%). The average PPC reaches $80 \%$ of planned activities. For this Workshop, the qualitative gains are of great importance. Daily takt time control meetings and production targets were kept with a focus on controlling production deviations and taking actions to solve problems.

Table 1: Results Summary

\begin{tabular}{|c|c|c|}
\hline Workshop & Qualitative Results & Quantitative Results \\
\hline \multirow[t]{4}{*}{ Analysis } & $\begin{array}{l}\text { Full analysis of the contract status; } \\
\text { Opportunity survey to reduce costs in the }\end{array}$ & $\begin{array}{l}59 \% \text { of front-line production activities do } \\
\text { not add value }\end{array}$ \\
\hline & order of $60 \%$ of the contract margin; & \multirow{3}{*}{$\begin{array}{l}\text { Only } 27 \% \text { of the predefined activities of } \\
\text { the Planning standards were met }\end{array}$} \\
\hline & $\begin{array}{l}\text { Identification of planning gaps and planning } \\
\text { routines not implemented }\end{array}$ & \\
\hline & $\begin{array}{l}\text { Office-field communication failure } \rightarrow \\
\text { absence of indicators }\end{array}$ & \\
\hline \multirow[t]{4}{*}{$\begin{array}{l}\text { Production } \\
\text { Planning }\end{array}$} & $\begin{array}{l}\text { Definition of responsibilities matrix and } \\
\text { schedule of production planning and control }\end{array}$ & $\begin{array}{l}93 \% \text { of the predefined activities of the } \\
\text { planning standards were met; }\end{array}$ \\
\hline & \multirow{2}{*}{$\begin{array}{l}\text { Implementation of Last Planner and control } \\
\text { of deviations at each change of shift with the } \\
\text { holding of quick response meetings }\end{array}$} & $\begin{array}{l}\text { Average PPC of } 80 \% \text { over the project } \\
\text { follow-up year }\end{array}$ \\
\hline & & \multirow{2}{*}{$\begin{array}{l}\text { Reduction of staff by detailing the } \\
\text { production strategy for each new } \\
\text { production step } \rightarrow 6 \% \text { reduction in each } \\
\text { new step }\end{array}$} \\
\hline & $\begin{array}{l}\text { Definition and implementation of operational } \\
\text { and managerial indicators }\end{array}$ & \\
\hline \multirow[t]{6}{*}{$\begin{array}{l}\text { Productivity } \\
\text { Workshop }\end{array}$} & $\begin{array}{l}\text { Definition of production takt and scaling of } \\
\text { resources to achieve it (OBC) }\end{array}$ & $\begin{array}{l}\text { Reduction of direct labor to each phase } \\
\text { (step) }\end{array}$ \\
\hline & \multirow{2}{*}{$\begin{array}{l}\text { Review of the plans of attack and change of } \\
\text { the conception of work performance on site }\end{array}$} & Step 3 - reduction of $42 \% \mathrm{mh} /$ ton \\
\hline & & Step 2 - reduction of $37 \% \mathrm{mh} /$ ton \\
\hline & \multirow{2}{*}{$\begin{array}{l}\text { Development of tools and devices that help } \\
\text { the activities of production and inspection of } \\
\text { activities }\end{array}$} & Step 6 - reduction of $7 \% \mathrm{mh} /$ ton \\
\hline & & $\begin{array}{l}20 \% \text { increase in overall contract } \\
\text { productivity }\end{array}$ \\
\hline & $\begin{array}{l}\text { Paced supply and Quality inspections of the } \\
\text { fronts according to takt }\end{array}$ & Global increase in gross margin of $46 \%$ \\
\hline
\end{tabular}

The delay described in the chapter 4.2.2 in the Step 1 was recovered; the activities and teams were sized to take account of takt time and the routines for managing goals acted to guarantee this pace. Overall, the general objective was met. The sustained new tools and 
Bernardo Martim Beck Da Silva Etges, Bruno Bronzatto Pereira,

Thiago José Salgado Da Silveira

productivity control guarantee reduction of $42 \%$ in $\mathrm{mh} /$ ton compared with the predicted rate (mh/ton) in the project budget for Step 3; reduction of $37 \%$ in $\mathrm{mh} /$ ton and $7 \%$ in $\mathrm{mh} /$ ton in Step 2 and Step 6 respectively. Comparing those results with the problematic Step 1, the Company A performed with an addition of $7 \%$ in $\mathrm{mh} /$ ton compared to the same predicted budget. The overall productivity was increased by $20 \%$, when compared to the estimated budget; and, the operational efficiency guaranteed an increase of $46 \%$ in the gross margin of the contract. To reach these results, otherwise the takt time control and deviations action plans, some operational improvements approaches were made: redesign of the assemblage strategy detailing the number of layers each labour should do in each step; implementing simple tools to assure quality during the assemblage; logistics preparation in the right sequence of brick assemblage; labour change, due the temperature, with stronger control.

\section{CONCLUSIONS: CHALLENGES AND SUSTAINABILITY}

The project presented led to good results for the Company A and to reviewing the internal procedures for planning work. A recurring challenge to Lean projects is resistance to change. We can consider that the case study described was successful in this aspect, because it succeeded in helping the team to internalize changes and to guarantee their motivation in constantly seeking continuous improvement. It is recommended that the planning and takt time control routines that have been incorporated into the present case be passed on to other the Company A projects, while always considering the alternatives of flexibility in the different contract models. In addition, it should motivate identifying companies that manage to balance the impact of an external presence such as consultancies in order to catalyse and ensure change under internal leaders of Lean Construction Projects.

\section{ACKNOWLEDGEMENTS}

We thank all the RIP-KAEFER subsidiary company in Brazil team involved in the project and we are also grateful to Steinbock Consulting for the theoretical support and methodological tools addressed.

\section{REFERENCES}

Ballard, G. (2000). "The Last Planner ${ }^{\mathrm{TM}}$ system of production control." PhD Thesis, School of Civil Engineering, The University of Birmingham, UK, 192 pp.

Dave, B, Boddy, SC and Koskela, LJ. (2010)."Improving information flow within the production management system with web services". Proceedings IGLC-18, July 2010, Technion, Haifa, Israel.

Frandson, A., Berghede, K., Tommelein, I. D. "Takt time planning for construction of exterior cladding". Proceedings IGLC-21, July 2013, Fortaleza, Brazil.

Frandson, A., Seppännen, O., Tommelein, I. D. "Comparison between location based management and takt time planning”. Proceedings IGLC- 23. July 2015, Perth, Australia 
Hopp, W.J., Spearman, M.L. (2008). “Shop Floor Control.” Factory Physics, Waveland Press, Long Grove, IL, p. 495.

Koskela, L. (1992). "Application of the New Production Philosophy to Construction", Technical Report No. 72, CIFE, Stanford University, CA.

Koskela, L. (2000). "An Exploration towards a Production Theory and its Application to Construction". PhD Diss., VTT Pub. 408, Espoo, Finland, 296 pp..

Liker, J. K. (2004). "The Toyota Way. 14 Management principles from the world greatest manufacturer". 1 ed. USA: McGraw-Hill. 352 pp.

Ohno, T. (1988). "Toyota Production System; Beyond large scale production". Productivity Press, Portland, Oregon.

Rother, M.; Shook, J. (2000). "Learning to see”. Brookline, Massachusetts, USA, 100 p.

Sacks, R., Radosavljevic, M., \& Barak, R. (2010). "Requirements for building information modeling based lean production management systems for construction". Automation in Construction, 19(5): 641-655.

Sage, D., A. Dainty, N., Brookes (2012). "A Strategy-as-practice exploration of Lean construction strategizing”. Building Research and Information, 40(2), 221-230.

Shingo, S. (1988). "Non-stock Production". Productivity Press, Cambridge

Shingo, S. (1989). "A study of the Toyota Production System from an industrial engineering viewpoint". Portland, OR: Productivity Press.

Spear, S. and Bowen, H.K. (1999). "Decoding the DNA of the Toyota Production System". Harvard Business Review, September, 97-106.

Womack, J.; Jones, D.; and Roos, D (1990). "The machine that changed the world".Rawson Associates, New York. 323 pp. 